Rev. Bras. Saúde Prod. Anim., Salvador, v.14, n.1, p.142-148 jan./mar., 2013 http://www.rbspa.ufba.br ISSN 15199940

\title{
Effects of cross-fostering on performance of piglets
}

\author{
Efeito da equalização de leitegadas sobre o desempenho de leitões
}

\author{
CAMARGO, Ederson Gomes ${ }^{1 *}$; REGO, Joseane Crystina Costa ${ }^{1}$; DIAS, Laila \\ Talarico $^{1}$; TEIXEIRA, Rodrigo de Almeida ${ }^{1}$
}

\author{
${ }^{1}$ Universidade Federal do Paraná, Departamento de Zootecnia, Curitiba, Paraná, Brasil. \\ *Endereço para correspondência: edersoncamargo@ufpr.br
}

\section{SUMMARY}

The high number of piglets born alive from hiperprolifics sows increases the variability of weight at birth and made many producers practice cross-fostering management, which consists in standardization of weight and number of piglets according to the sow ability. To evaluate the effect of cross-fostering on performance and mortality occurrence of piglets, historical data were studied from two producers of the Midwest region of Santa Catarina-Brazil. Were weighed 1440 piglets at birth, weaning and 37 days post weaning from 130 commercial sows of Agroceres PIC®. The adjusted weights at 21 and 58 days old and their respective gain were submitted to multiple regression analysis using the GLM procedure of SAS Statistical Software (2005), and occurrence of mortality was studied by GENMOD procedure. For performance traits were considered fixed effects the cross-fostering, contemporary group and covariables the birth weight or weaning, the number of piglets after equalization, number of weaned piglets, linear and quadratic effects of sow parity; the weight at birth were included as covariable for occurrence of mortality. Cross-fostered piglets weighed 207 grams less than biological piglets $(\mathrm{P}<0.01)$ and had lesser mortality between lightest piglets. However, the littermate equalization did not promote differences in growth period between cross-fostered and biological piglets.

Keywords: littermate, standardization, swine, weight.

\section{RESUMO}

$\mathrm{O}$ aumento do número de leitões nascidos vivos de fêmeas hiperprolíficas aumenta a variabilidade do peso ao nascer e faz muitos produtores praticarem a equalização de leitegadas, que consiste na uniformização do peso e número de leitões de acordo com a capacidade da matriz. Com o objetivo de avaliar o efeito da equalização de leitegadas sobre o crescimento e mortalidade de leitões, estudaram-se dados históricos de duas unidades produtoras de leitões da região centrooeste de Santa Catarina. Foram pesados 1440 leitões ao nascer, desmame e saída de creche, nascidos de 130 matrizes comerciais Agroceres PIC®. Os pesos ajustados aos 21 e 58 dias de idade e os respectivos ganhos médios diários foram submetidos à análise de regressão múltipla por meio do procedimento GLM do programa estatístico SAS (2005), e a ocorrência de mortalidade foi estudada pelo procedimento GENMOD do mesmo programa. Foram considerados como efeitos fixos a transferência e grupo de contemporâneos e como covariáveis o peso ao nascer ou desmame, número de leitões após equalização e número de leitões desmamados, além dos efeitos linear e quadrático da ordem de parto da matriz; no estudo da ocorrência de mortalidade o peso ao nascer foi considerado como covariável. Os leitões adotivos pesaram 207 gramas a menos que leitões biológicos no período da maternidade $(\mathrm{P}<0,01)$ e maior sobrevivência entre os leitões leves. No entanto, o efeito da equalização não promoveu diferenças no período de creche entre os leitões adotivos e aqueles criados por suas mães biológicas.

Palavras-chave: leitegada; padronização; peso; suíno. 


\section{INTRODUCTION}

Demand for improving productivity on pig fair makes number of weaned piglets/sow/year to be even more important. The litter size at birth has a direct impact on this index, but the use of hiperprolifics sows increase variability on the piglet's birth weight, affecting then performance and occurrence of mortality.

To reduce these losses, many producers realize the cross-fostering of litters as a management tool, which aims to standardize the weight and equalize the number of piglets per litter according to the sow capacity (Heim, 2010), with an objective to improving performance and survival of piglets from large litters (NealIrvin, 1991).

Many studies have already been conducted in order to explain the effect of the transfer of piglets on their performance and pre-weaning mortality (Bierhals et al., 2010; Heim et al., 2012), but, some proposed designs are far from practiced, since cross-fostering is often done indiscriminately by producers (Heim, 2010), especially in challenging conditions or when they receive bonus in meeting index as number of weaned piglets.

Transferring of piglets must occur between six and 24 hours after birth (RobertMartineau, 2001), however, the success depends of period after the birth, origin of the piglets (biological or adoptive), parity of biological or adoptive sow, number and size of the pigs that compose the litter, besides the factors related to the sow as the number of functional teats, milk production, colostrum's quality, body condition at farrow date, feed consumption, maternal ability, environmental conditions that directly affect the feed intake during lactating of sows may affect their milk production (Bierhals et al., 2010).

Few studies were found about the consequences in cross-fostering on performance of piglets associating several effects simultaneously, and the use of general linear models to analyze multiples factors at the same time involved in this practice may be important, approaching to a real condition.

The multiple regression analysis allows to find the better model to describe some biological process, estimates parameters to each variable, in addition, analyzes the effect of each variable separately and predict values based on new measurements (KapsLamberson, 2004).

The aim of this study was measure the performance of cross-fostered piglets and biological piglets, from their birth to 58 days old, when submitted to this practice between sows of first to seventh parity.

\section{MATERIAL AND METHODS}

Historical data from two swine producers located in south of Brazil were analyzed, which 1.440 piglets from 130 sows of commercial lines Camborough 23 and 25 (C-23 and C25) of Genetics Agroceres PIC. Data refers to 11.7 piglets born alive/sow on winter of 2010, individually identified and weighed after birth, and crossfostering occurred between six and 24 after birth, limiting between females with approximate time after end of parturition.

Cross-fostering in both producers were similar and considered the standardization the number and weight of piglets by littermate according to the number of functional teats of each sow, and then, 
parity of foster females were randomly chosen except for primiparous, avoiding transfer heavier piglets to this category.

The following performance traits studied were individual body weight at birth (BWt), adjusted weight by linear interpolation at 21 and 58 days (21-d $\mathrm{Wt}$ and 58-d Wt), average daily gain from birth to 21 and 58 days (Gain to 21-d and Gain to 58-d) and ocurrence of pre-weaning mortality (PWM).

Piglets born in the same farm, date and sex were considered contemporaneous groups (CG). Data edition considered only sows of first to seventh parity, littermate sizes from 8 to 14 piglets after cross-fostering and 8 to 12 at weaning, and incomplete data were excluded.

Database was analyzed using the GLM procedure of SAS statistical software (2002), with the follow linear model: $Y_{n}$ $=\mathrm{CG}+\mathrm{CF}+\mathrm{Wt}+\mathrm{LS}+\mathrm{W}+\mathrm{P}+\mathrm{P}^{2}+\varepsilon$, where: $\mathrm{Y}=$ variable studied $(21-\mathrm{d} \mathrm{Wt}$, 58-d Wt, gains to 21 and 58 days); CG = contemporary group effect; $\mathrm{CF}=$ cross-fostering effect; $\mathrm{Wt}=$ covariable body weight at beginning of the test: body weight at birth (BWt) for traits21$\mathrm{d}$ Wt and Gain to 21-d; weight at 21 days for traits 58-dWt and gain to 58-d; $\mathrm{LS}=$ littermate size after crossfostering; $\mathrm{W}=$ number of weaned piglets by littermate; $\mathrm{P}=$ parity effects; $\varepsilon=$ random error associated with each observation $\mathrm{Y}$.

Cross-fostering effects on PWM was evaluated by PROC GENMOD of SAS (SAS Institute, 2005), considering only BWt as covariable, excluding piglets died in farrow date.

\section{RESULTS AND DISCUSSION}

After edition, database had 1,175 piglets from 110 sows, which 1,105 weaned and 70 died during pre-weaning period. Those weaned, 610 remained in their nonfoster sows and 495 pigs were transferred between sows of different parities (Table 1), except to piglets born from gilts, which were fostered to others gilts, remaining in the same parity sow.

High number of piglets was fostered $(44.8 \%)$ (Table 1), probably due to the higher coefficient of variation of the BWt (Table 2) than found by Milligan et al. (2002), however, high coefficients of variation for $\mathrm{BWt}$ were found both in small $(26.3 \%)$ and large litters $(22.3 \%)$ (Lima, 2007). For Milligan et al. (2002), variations in $\mathrm{BWt}$ is an important predictor for mortality occurrence independent of pre-weaning performance, litter size and dam parity. Another motive for high rate of fostering may be due absence of tool to monitor this management, making an unknown practice to the managers.

The overall mean BWt was $1.509 \pm 0.348 \mathrm{~kg}$, which cross-fostered piglets weighed $1.397 \pm 0.368 \mathrm{~kg}$, while biological $1.600 \pm 0.302 \mathrm{~kg}$ (Table 3), showing a tendency to transfer lighter piglets, similar to Neal \& Irvin (1991), who compared biological to adoptive piglets with 521 grams of difference of BWt for biological.

Studying variables $21-\mathrm{d} \mathrm{Wt}$ and Gain to 21-d, all effects included in the model were significant at $1 \%$ of probability (CG, CF, BWt, LS and W) or 5\% (P and $\mathrm{P}^{2}$ ) - (Table 4).

Cross-fostered weighed $5.655 \pm 1.448 \mathrm{~kg}$ at 21-d while those biological $6.526 \pm 1.385 \mathrm{~kg}$, corresponding to $0.234 \pm 0.059$ and $0.202 \pm 0.060 \mathrm{~kg} /$ day in gain to $21-\mathrm{d}$, respectively. The crossfostering causes a reduction of 207 grams on 21-d Wt and 10 grams on gain to $21-\mathrm{d}(\mathrm{P}<0.01)$. 
Rev. Bras. Saúde Prod. Anim., Salvador, v.14, n.1, p.142-148 jan./mar., 2013 http://www.rbspa.ufba.br ISSN 15199940

Table 1. Number of piglets fostered for each foster dam parity and overall number of observations $(\mathrm{N})$ by parity

\begin{tabular}{|c|c|c|c|c|c|c|c|c|c|c|}
\hline & & \multicolumn{7}{|c|}{ Foster dam parity } & \multicolumn{2}{|c|}{$\mathrm{N}$ (total of piglets) } \\
\hline & & 1 & 2 & 3 & 4 & 5 & 6 & 7 & Adoptives & Biologicals \\
\hline \multirow{7}{*}{ 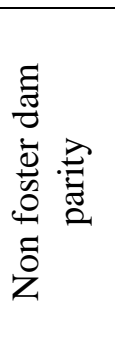 } & 1 & $67^{*}$ & 3 & 1 & 2 & 0 & 0 & 0 & 73 & 114 \\
\hline & 2 & 0 & 7 & 17 & 2 & 6 & 11 & 2 & 45 & 51 \\
\hline & 3 & 4 & 15 & 25 & 9 & 13 & 14 & 5 & 85 & 161 \\
\hline & 4 & 2 & 7 & 13 & 4 & 3 & 11 & 4 & 44 & 117 \\
\hline & 5 & 6 & 20 & 18 & 5 & 6 & 34 & 13 & 102 & 71 \\
\hline & 6 & 1 & 22 & 20 & 14 & 21 & 31 & 7 & 116 & 65 \\
\hline & 7 & 0 & 6 & 6 & 2 & 13 & 3 & 0 & 30 & 31 \\
\hline Total & & $80^{*}$ & 80 & 100 & 38 & 62 & 104 & 31 & $495(44.8 \%)$ & $610(55.2 \%)$ \\
\hline
\end{tabular}

"e.g.: 80 piglets were fostered from distinct parity to gilts (first parity), which 67 born from others gilts.

Table 2. Number of observations, average and standard deviation (SD) of littermate birth weight before and after cross-fostering by dam parity

\begin{tabular}{ccccc}
\hline \multirow{2}{*}{ Parity } & \multicolumn{3}{c}{ Before Cross-fostering } & \multicolumn{2}{c}{ After Cross-fostering } \\
\cline { 2 - 5 } & $\mathrm{N}$ & Average $\pm \mathrm{SD}^{1}$ & $\mathrm{~N}$ & ${\text { Average } \pm \mathrm{SD}^{1}}^{1}$ \\
\hline 1 & 187 & $1.356 \pm 0.253$ & 194 & $1.350 \pm 0.252$ \\
2 & 96 & $1.575 \pm 0.395$ & 131 & $1.485 \pm 0.440$ \\
3 & 246 & $1.546 \pm 0.370$ & 261 & $1.540 \pm 0.383$ \\
4 & 161 & $1.590 \pm 0.284$ & 155 & $1.573 \pm 0.288$ \\
5 & 173 & $1.544 \pm 0.369$ & 133 & $1.531 \pm 0.327$ \\
6 & 181 & $1.469 \pm 0.380$ & 169 & $1.551 \pm 0.335$ \\
7 & 61 & $1.540 \pm 0.280$ & 62 & $1.612 \pm 0.303$ \\
\hline
\end{tabular}

${ }^{\mathrm{I}} \mathrm{kg}$.

Table 3. Averages and standard deviations (SD), sources of variations (Mean Square) and determination coefficients $\left(\mathrm{R}^{2}\right)$ obtained from analysis of variance for performance traits: weight at 21 and 58 days $(21-\mathrm{d} \mathrm{Wt}$; $58-\mathrm{d} \mathrm{Wt})$ and respective gains to 21 and 58 days

\begin{tabular}{|c|c|c|c|c|c|c|c|c|c|c|}
\hline Traits & $\begin{array}{l}\text { Mean } \pm \\
\text { SD }\end{array}$ & $\mathrm{CG}$ & $\mathrm{CF}$ & $\mathrm{Wt}$ & LS & W & $\mathrm{P}$ & $\mathrm{P}^{2}$ & $\begin{array}{c}\text { residu } \\
\text { al }\end{array}$ & $\mathrm{R}^{2}$ \\
\hline $\begin{array}{l}21-\mathrm{d} \\
\mathrm{Wt}^{1}\end{array}$ & $\begin{array}{c}6.13 \pm 1 \\
.11\end{array}$ & $3.274^{* *}$ & $8.301^{* *}$ & $376.340^{* * *}$ & 19.573 & $6.614^{* *}$ & 19.029 & $7.756^{*}$ & 1.232 & $\begin{array}{c}0.4 \\
5\end{array}$ \\
\hline $\begin{array}{c}\text { Gain to } \\
21-d^{2}\end{array}$ & $\begin{array}{c}220 \pm 5 \\
2.85\end{array}$ & $0.007^{* *}$ & $0.018^{* *}$ & $0.194^{* *}$ & $0.044^{* *}$ & $0.015^{* *}$ & $0.043^{* *}$ & $0.017^{*}$ & 0.003 & $\begin{array}{c}0.3 \\
0\end{array}$ \\
\hline $\begin{array}{l}58-\mathrm{d} \\
\mathrm{Wt}^{1}\end{array}$ & $\begin{array}{c}19.02 \pm \\
2.57\end{array}$ & 23.418 & $\underset{\mathrm{NS}}{18.578}$ & $\begin{array}{c}1,278.48 \\
8^{* *}\end{array}$ & 15.436 & 42.462 & 78.102 & $\underset{* *}{68.008}$ & 6.631 & $\begin{array}{c}0.4 \\
7\end{array}$ \\
\hline $\begin{array}{c}\text { Gain to } \\
58-d^{2}\end{array}$ & $\begin{array}{c}341 \pm 6 \\
9.58\end{array}$ & $0.017^{* *}$ & $0.013^{N}$ & $0.094^{* *}$ & $0.011^{*}$ & $0.031^{* *}$ & $0.057^{* *}$ & $0.050^{* *}$ & 0.005 & $\begin{array}{c}0.2 \\
2\end{array}$ \\
\hline
\end{tabular}

$\mathrm{GC}=$ contemporary group effect; $\mathrm{CF}=$ cross-fostering effect; $\mathrm{Wt}=$ covariable body weight at beginning of the test: birth weight (BW) for traits $21-\mathrm{d}$ Wt and gain to 21-d; weight at 21 days for traits 58-d Wt and gain to 58-d; LS = littermate size after cross-fostering; $\mathrm{W}=$ number of weaned piglets by littermate; $\mathrm{P}=$ parity effects; ${ }^{* *} \mathrm{P}<0.01 ;{ }^{*} \mathrm{P}<0.05 ;{ }^{\mathrm{NS}}$ not significant. 
Rev. Bras. Saúde Prod. Anim., Salvador, v.14, n.1, p.142-148 jan./mar., 2013 http://www.rbspa.ufba.br ISSN 15199940

Table 4. Number of observations (N), average and standard deviation (SD) of weaned and non-weaned birth weight (BW), weight at 21 days (21-d Wt) and 58 days (58-d Wt) and respective gains to 21 days (Gain to 21-d) and 58 days (Gain to $58-d)$

\begin{tabular}{|c|c|c|c|c|c|c|}
\hline \multirow{2}{*}{ Trait } & \multicolumn{2}{|c|}{ Biological } & \multicolumn{2}{|c|}{ Cross-fostered } & \multicolumn{2}{|r|}{ Total } \\
\hline & $\mathrm{N}$ & Average \pm SD & $\mathrm{N}$ & Average \pm SD & $\mathrm{N}$ & Average $\pm S D$ \\
\hline Weaned $\mathrm{BW}^{1}$ & 610 & $1.600 \pm 0.302 \mathrm{a}$ & 495 & $1.396 \pm 0.368$ & 1105 & $1.509 \pm 0.348$ \\
\hline$\left(\right.$ non-weaned BW) ${ }^{1}$ & (27) & $(1.239 \pm 0.403)$ & (43) & $(1.067 \pm 0.353)$ & (70) & $(1.133 \pm 0.379)$ \\
\hline $21-\mathrm{d} \mathrm{Wt}^{1}$ & 610 & $6.526 \pm 1.385$ & 495 & $5.655 \pm 1.448$ & 1105 & $6.136 \pm 1.478$ \\
\hline Gain to $21-\mathrm{d}^{2}$ & 610 & $0.234 \pm 0.059$ & 495 & $0.202 \pm 0.060$ & 1105 & $0.220 \pm 0.062$ \\
\hline $58-\mathrm{d} \mathrm{Wt}^{1}$ & 252 & $18.992 \pm 3.905$ & 166 & $18.277 \pm 3.768$ & 418 & $18.707 \pm 3.862$ \\
\hline Gain to $58-\mathrm{d}^{2}$ & 252 & $0.333 \pm 0.086$ & 166 & $0.336 \pm 0.080$ & 418 & $0.334 \pm 0.084$ \\
\hline
\end{tabular}

Robert \& Martineau (2001) studied 27 multiparous sows and concluded that piglets cross-fostered over a day old grew slowly, and the successfully of cross-fostering occur when realized in the first day of life (Bierhals et al., 2011), moreover, contributes in reduce the variations of average daily gain and weight at weaning (Furtado et al., 2009). Heim (2010) compared groups of litter $100 \%$ adoptive, $100 \%$ biological or $50 \%$ biological and $50 \%$ adoptive. Bierhals (2010) studied sows from first to fifth parity and concluded that performance of the piglets is not affected by cross-fostering when occur between sows with the same parities.

Negative effects of transferring piglets on this study were also found in other studies. Wattanaphansak et al. (2002) related that cross-fostering is generally not a good management practice, as negatives effects on piglet survival (2$3 \%$ ) and gain (7-9\%). Bandrick et al. (2011) proved that cross-fostering affects transfer of immunity to piglets through colostrum.

Higher 21-d Wt was observed in sows at sixth parity (Figure 1) and differed from Holanda et al. (2005), who have not established a correlation matrix between 21-d Wt and sow parity.

Regarding the effect of litter size on piglet performance, litters with 12 or less piglets after cross-fostering had higher performance $(\mathrm{P}<0.01)$. The changes in 21-d Wt are caused mainly by variations in size of litter and this is the most influential factor on the growth of piglets during pre-weaning period and gain to 21-d may be influenced by the number of piglets born alive (Holanda et al., 2005).

Litters with at least 10 piglets at wean were heavier at 21-d. The overall mortality rate was $6.3 \%$ and crossfostering did not affect the PWM, when using BWt as covariable ( $\mathrm{P}>0.05)$. Neal and Irvin (1991) observed that adoptive piglets had lower survival to 21-d and 42-d. Piglets born lighter have highest chance to survive in small litters irrespective of the birth weight of their littermates (DeenBilkei, 2004), however, for Bierhals et al. (2010), the mortality until 18 days old of piglets biological or adoptive does not differ, but BWt must be considerate on association between transfer and mortality.

In this study, $74.3 \%$ of piglets dead had BWt less than $1.400 \mathrm{~kg}$ and fostering reduces the mortality in $1.8 \%(\mathrm{P}<0.01)$, similar to Heim (2010), that preweaning mortality was higher in biological piglets $(62.5 \%)$ compared to adoptive piglets $(15.4 \%)$, considering lesser piglets (lighter than 800 grams) 
from litters with similar BWt. Crossfostering of piglets promotes benefit only in little and weak piglets, since considered a proper intake of colostrum after birth (Wattanaphansak et al., 2002), in addition, cross-fostering according to each weight range (DeenBilkei, 2004).

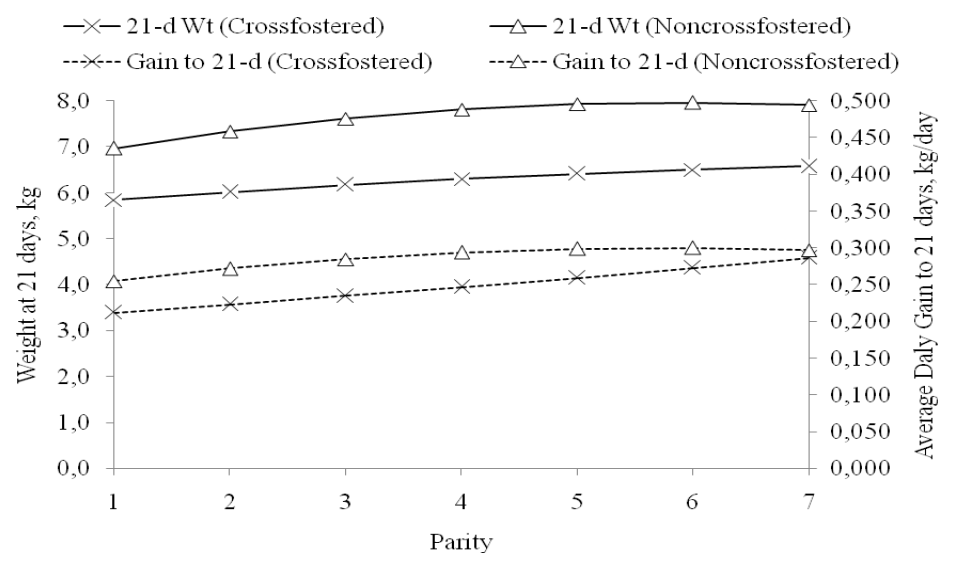

Figure 1 . Weight at 21 days and average daily gain to 21 days of cross-fostered and biological weaned piglets by dam parity

Cross-fostering was not significant to 58-d Wt $(\mathrm{P}=0,095)$ and Gain to 58-d $(\mathrm{P}=0,093)$ and analysis of variance had lesser determination coefficient for these traits (Table 2), probably due loss of information occurred between 21 to 58 days old, which 418 piglets weighed $18.707 \pm 3.862 \mathrm{~kg}$ at $58-\mathrm{d}$ and gained $0.334 \pm 0.084 \mathrm{~kg} /$ day, in average (Table 3). Table 3 also show that transfer was not an important source of variation on traits $58-\mathrm{d} \mathrm{Wt}$ and gain to 58-d $\quad(\mathrm{P}=0.0950 ; \quad \mathrm{P}=0.0934)$. Others effects included for these traits were significant at $1 \%$ of probability (CG, 21-d Wt, LS, W and P). Fostered piglets had a reduced pre-weaning gain, but not while growing-finishing or finishing (NealIrvin, 1991), but next studies with best quality database can show negative effects of transfer piglets on postweaning performance.

Cross-fostering is an important farrowing house management practice for farms with high variability of piglet's weight at birth and helps to reduce pre-weaning mortality in lighter piglets at birth. This practice can affect the growth rate during pre-weaning period; however, postweaning performance traits are not affected by cross-fostering.

\section{REFERENCES}

BANDRICK, M.; PIETERS, M.;

PIJOAN, C.; BAIDOO, S.K.; MOLITOR, T.W. Effect of crossfostering on transfer of maternal immunity to Mycoplasma hyopneumoniae to piglets. Veterinary

Record, v.168, n.4, p.100, 2011.

BIERHALS, T.; HEIM, G.; PIUCO, P.; WENTZ, I.; BORTOLOZZO, F.P. Uso prático do manejo de uniformização de leitegadas. Acta Scientiae

Veterinariae, v.38, n.1, p.141-157, 2010. 
Rev. Bras. Saúde Prod. Anim., Salvador, v.14, n.1, p.142-148 jan./mar., 2013 http://www.rbspa.ufba.br ISSN 15199940

BIERHALS, T.; MELAGGI, A.P.G.; HEIM, G.; BERNARDI, M.L.; WENTZ, I.; BORTOLOZZO, F.P. Performance of litter after cross-fostering of piglets between females of parity order 1 and 5 . Acta scientiae veterinariae, v.39, n.1, p.942, 2011.

DEEN, M.G.H.; BILKEI, G. Crossfostering of low-birthweight piglets. Livestock Production Science, v.90, n.23, p.279-284, 2004.

FURTADO, C.S.D.; MELAGGI, A.P.G.; CYPRIANO, C.R.; WENTZ, I.; BERNARDI, M.L.; BORTOLOZZO, F.P. Desempenho de leitões lactentes e produção de leite de acordo com o teto da mamada. Ciência Animal Brasileira, v.10, n.1, p.77-82, 2009.

HEIM, G. Comportamento dos leitões e das fêmeas durante as mamadas $e$ desempenho dos leitões quando submetidos a três diferentes manejos de uniformização. 2010. 66p. Dissertação (Mestrado em Medicina Veterinária) - Universidade Federal do Rio Grande do Sul, Rio Grande do Sul.

HEIM, G.; MELAGGI, A.P.G.; BIERHALS, T.; SOUZA, L.P.; FRIES, H.C.C.; PIUCO, P.; SEIDEL, E.; BERNARDI, M.L.; WENTZ, I.; BORTOLOZZO, F.P. Effects of crossfostering within $24 \mathrm{~h}$ after birth on preweaning behaviour, growth performance and survival rate of biological and adopted piglets. Livestock Science, v.150, p.121-127, 2012.

HOLANDA, M.C.R.; BARBOSA, S.B.P.; SAMPAIO, I.B.M.; SANTOS, E.S.; SANTORO, K.R. Tamanho da leitegada e pesos médios, ao nascer e aos 21 dias de idade, de leitões da raça Large White Arquivo Brasileiro de Medicina Veterinária e Zootecnia, v.57, n.4, p.539-544, 2005.
KAPS, M.; LAMBERSON, W.R. Biostatistics for Animal Science. Columbia, USA: CABI Publishing, 2004.

LIMA, G.J.M.M.D. Como manejar uma fêmea hiperprolífica e alimentar os seus leitões. Acta Scientiae Veterinariae, v.35, p.29-36, 2007.

MILLIGAN, B.N.; DEWEY, C.E.; GRAU, A.F. Neonatal-piglet weight variation and its relation to pre-weaning mortality and weight gain on commercial farms. Preventive

Veterinary Medicine, v.56, p.119-127, 2002.

NEAL, S.M.; IRVIN, K.M. The effects of cross-fostering pigs on survival and growth. Journal of Animal Science, v.69, p.41-46, 1991.

ROBERT, S.; MARTINEAU, G.P. Effects of repeated cross-fosterings on preweaning behavior and growth performance of piglets and on maternal behavior of sows. Journal of Animal Science, v.79, p.88-93, 2001.

SAS Institute. SAS User's guide: statistics. Version 9.1.3. Cary, N.C., 2005.

WATTANAPHANSAK, S.; LUENGYOSLUECHAKUL, S.; LARRIESTRA, A.; DEEN, J. The impact of cross-fostering on swine production. Thailand Journal Veterinary Medicine, v.32, p.6, 2002.

Data de recebimento: 12/09/2012

Data de aprovação: 22/03/2013 